Int. J. Dev. Biol. 66: 51-58 (2022)

https://doi.org/10.1387/ijdb.220010ik

\title{
Heterogeneity of quiescent and active neural stem cells in the postnatal brain
}

\author{
DIMITRIOS DIMITRAKOPOULOS, DIMITRIOS KAKOGIANNIS, ILIAS KAZANIS*
}

Lab of Developmental Biology, Department of Biology, University of Patras, Greece

\begin{abstract}
In the postnatal mammalian brain, neurogenic activity is retained in anatomically restricted areas, driven by pools of Neural Stem Cells (NSCs). These cells and their progeny have been studied intensively as potential targets for regenerative treatments, aiming at either their in situ manipulation or their use as sources of cells for transplantation-based strategies. Although their full identity, heterogeneity and differentiation potential remain elusive, due to the absence of specific cell-type markers, our knowledge of their properties is constantly expanding. Here, we focus on the NSC niche that is located at the Subependymal Zone (SEZ/ also known as Subventricular Zone) of the lateral ventricles of the brain. We review, summarize and explain the different faces of the NSC, as they have been described, using a wide range of experimental approaches, over a time-frame of three decades: the primitive, definitive, quiescent or activated NSC. We also review the growing evidence of the existence of latent NSCs outside of niches, in the brain parenchyma, that constitute promising new therapeutic targets, complemented by the novel technologies of in vivo cell reprogramming.
\end{abstract}

KEYWORDS: neural stem cell, Subependymal Zone, Subventricular Zone, quiescence, neurogenesis

\section{Quiescence in stem cells}

Tissue-specific, or adult/ postnatal stem cells are cells that retain a high self-renewal potential and can generate progeny of a wide, albeit tissue-specific, differentiation range. Depending on the system, they exhibit distinct modes of activation/ inactivation phases. For example, in the hematopoietic and intestinal systems, they remain in a "frequent activation" mode, with their pool constantly producing high numbers of progeny. In the mammary gland, they remain inactive and enter a "high activation mode" depending on lactation needs. In the postnatal mammalian brain, Neural Stem Cells (NSCs) are thought to act in a "slow activation" mode, with their pool constantly producing low numbers of progeny. To facilitate this behavior, stem cells can reside in a state of reversible cell-cycle arrest, or quiescence, for prolonged periods of time. Although quiescence has long been viewed as a ubiquitous low-activity state, increasing evidence suggests that it represents a continuum of substates of poised potential and active restraint, as stem cells "idle" in anticipation of activation, proliferation, and differentiation (Dulken et al., 2017; van Velthoven and Rando, 2019). Quiescent stem cells are largely dormant, meaning that they lack expression of markers of proliferation, such as Ki67 and
MCM2, that are expressed in actively dividing cells, but not during G0 (Maslov et al. 2007). Other markers of proliferation such as proliferating cell nuclear antigen (PCNA), and phospho-Histone $\mathrm{H} 3$ are also extensively used to distinguish quiescent from proliferating cells. Cells in $\mathrm{G} 0$ and in $\mathrm{G} 1$ have unreplicated genomes, so they contain equal DNA content, but G0 cells tend to be less transcriptionally active; thus, they have a lower total RNA content (Toba et al., 1995). In the absence of cell cycle related processes, quiescent cells have minimal metabolic requirements and avoid intensive energy consumption by keeping protein synthesis at a minimal level (Buttgereit and Brand, 1995). Within the neural stem

\footnotetext{
Abbreviations used in this paper: aNSCs, activated Neural Stem Cells; BMPs, Bone Morphogenetic Proteins; CSF, Cerebrospinal Fluid; Dcx, Doublecortin; DNs, Dopaminergic Neurons; EGF, Epidermal Growth Factor; EGFR, Epidermal Growth Factor Receptor; FGF, Fibroblast Growth Factor; GFAP, Glial Fibrillary Acidic Protein; INF, Interferon; LRIG1, Leucine Rich Repeats and Immunoglobulin Like Domains 1; MCAO, Middle Cerebral Artery Occlusion; NBs, Neuroblasts; NPCs, Neural Progenitor Cells; NSCs, Neural Stem Cells; PCNA, Proliferating Cell Nuclear Antigen; PD, Parkinson's disease; qNSCs, quiescent Neural Stem Cells; SEZ, Subependymal Zone; Shh, Sonic Hedgehog; SN, Substantia Nigra; TAPs, TransientAmplifying Progenitors; V-SVZ, Ventricular-Subventricularzone.
}

*Address correspondence to: Ilias Kazanis. Lab of Developmental Biology, $2^{\text {nd }}$ floor, Department of Biology, University of Patras, Rio University Campus, 26504, Greece.
Tel: +302610969251. E-mail: ikazanis@upatras.gr | web: https://www.researchgate.net/lab/Ilias-Kazanis-Lab | https://orcid.org/0000-0003-1035-0584

Submitted: 20 September, 2021; Accepted: 12 December, 2021; Published online: 21 February, 2022

ISSN: Online 1696-3547, Print 0214-6282

(9) 2021 UPV/EHU Press

Printed in Spain 
cell lineage, quiescent NSCs exhibit lower protein synthesis rates than more downstream committed neural progenitors (LlorensBobadilla et al., 2015).

Several recent studies have shown the existence of distinct levels of quiescence in adult stem cells. For example, quiescent satellite (muscle) stem cells can cycle between two molecularly distinct states: a "canonical" G0 quiescent state and a primed but still quiescent state, termed "G-alert" (Rodgers et al., 2014). Injury to the tissue can be a stimulus that will induce quiescent stem cells to become activated and move from G0 to G1 (van Velthoven and Rando, 2019). Similarly, a "primed-quiescent" state has also been identified in NSCs (Llorens-Bobadilla et al. 2015; Marqués-Torrejón et al. 2021), with primed quiescent NSCs having increased protein synthesis rates when compared with their more deeply quiescent counterparts. This suggests that translational activation is one of the earlier events in the exit from quiescence (Llorens-Bobadilla et al., 2015). Furthermore, primed quiescent NSCs display accelerated entry into the cell cycle. Studies of the varying depths of quiescence have also highlighted the limited information regarding the $\mathrm{G} 0$ to $\mathrm{G} 1$ transition. Currently, no G0/G1 checkpoint has been identified and no markers can definitively distinguish G0 from early G1. Overall, the quiescent stem cells in "G-alert", or the primed quiescent stem cells, exhibit enhanced regenerative capacity, since they show accelerated entry into the cell cycle and increased potential to give rise to progenitors, which strongly indicates that the position of a stem cell within the quiescence cycle impacts stem cell function (van Velthoven and Rando, 2019).

In this study, we will focus mainly on the quiescence/ activation of NSCs in one of the postnatal brain NSC niches, that of the Subependymal Zone (SEZ). We will also review the evidence of the presence of latent neural progenitors in areas of the brain parenchyma, such as the cortex, the striatum and the substantia nigra, areas that seem to harbor reprogrammable astrocytes. It should be noted that NSCs shuttling between quiescence and activation are also found in the Subgranular Zone of the hippocampus, but these are reviewed elsewhere (Lugert et al., 2010). The ability to identify and isolate quiescent NSCs (qNSCs) from the adult brain offers a new view of these cells, allowing for studies on their intrinsic and extrinsic molecular regulation and on definition of their dynamics during development and ageing. Understanding the biology of stem cell quiescence and activation will ultimately provide an insight into how NSCs might be contributing to brain pathology and show whether they can be harnessed for brain repair, particularly because qNSC activation is increasingly recognized as one of the critical barriers to neurogenesis (Kalamakis et al., 2019). This is even more crucial given that quiescent NSCs, marked by the expression of glial fibrillary acidic protein- $\delta$ (GFAP $\delta$ ), have also been identified in the human SEZ (van den Berge et al., 2010).

\section{Quiescent and activated neural stem cells in the SEZ}

The Subependymal Zone (also known as Ventricular- Subventricular zone (V-SVZ)) of the lateral ventricles is one of the areas of the adult rodent brain where new neurons are continuously generated from NSCs (Fig. $1 \mathrm{~A}, \mathrm{~B}$ ). Currently, there is no specific marker for these NSCs, but their presence has been predicted and accepted since the end of the 1990s on the basis of multiple observations: a) the intense mitotic activity detected in the SEZ (Fig. $1 A, B, D$ ) that is physically linked to the chain migration of neuroblasts to the ipsilateral olfactory bulb. b) The reconstitution of neurogenesis, which follows a specific cell-type hierarchy, after its depletion via the administration of the antimitotic drug AraC (Doetsch et al., 1999). c) The presence of colony-forming cells when the SEZ is dissociated (Codega et al., 2014). How can these NSCs be identified? The NSCs of the SEZ (also known as type B1 cells) are a subtype of astrocytes, expressing GFAP (Imura et al., 2003) (Fig. 1 B,C); thus, one approach is to look for mitotic astrocytes within the $30 / 50 \mu \mathrm{m}$ wide zone (in the mouse or the rat brain, respectively) that hosts proliferation at the walls of the lateral ventricles (Kazanis and ffrench-Constant, 2012)(Fig. 1G). The immunohistochemical analysis of the SEZ in different conditions and, in some cases, using unbiased morphometric tools, has led to the most probable description of the "typical" NSCs. They have radial morphology and span different compartments of the stem cell niche. Their apical processes contact the lateral ventricle at the center of pinwheel structures formed by ependymal cells and are tasting signals of the cerebrospinal fluid (CSF) via a primary cilium (Fig. 1C), while their basal processes contact blood vessels, which are an important proliferative sub-niche in the adult SEZ (Mirzadeh et al., 2008; Shen et al., 2008; Tavazoie et al., 2008; Delgado et al., 2021). This type of analysis is in constant evolution, with very recent work identifying NSCs with processes running parallel to the ventricular wall, as well as a new subgroup named "gorditas" (Delgado et al., 2021). Therefore, another approach for identifying NSCs is to look for astrocytes of specific morphologies (Delgado et al., 2021), or even to limit the area of investigation to the first periventricular $5 \mu \mathrm{m}$ zone (Zhao et al., 2021).

A few reports have suggested the existence of a pool of NSCs that are GFAP- and probably rest at the top of the lineage hierarchy. These have been named primitive NSCs, express low levels of the pluripotency marker Oct4, are rare, and undergo asymmetric divisions exhibiting a long cell cycle time of 3-5 months (Sachewsky et al., 2019). Primitive NSCs are transformed into definitive NSCs, marked by the upregulation of expression of GFAP and Nestin, and exhibit a cell-cycle of 2-4 weeks. The presence of such GFAP null NSCs is supported by the observation that after the total depletion of GFAP+ cells, via the selective expression of herpes simplex virus thymidine kinase, low levels of neurogenesis persist in the periglomerular area of the olfactory bulbs (Snyder et al., 2016). What was typically accepted to be the bona fide NSC was a GFAP+, slowly-cycling, BrdUretaining cell (Kazanis et al., 2010)(Fig. 1E), probably coinciding with the definitive NSC described above. The majority of these cells are qNSCs (type B1q cells) that transit towards a proliferative, activated state (aNSCs or type B1a cells) characterized by the expression of epidermal growth factor receptor (EGFR) and Nestin (Delgado et al., 2021) as well as by upregulated integrin- $\beta 1$ expression (Kazanis et al., 2010)(Fig. 1F). aNSCs produce neural progenitor cells (NPCs or transient amplifying progenitors (TAP) or type C cells), a highly proliferative cell population that expresses markers of early neuronal or oligodendroglial cell fate (Hack et al., 2005). Finally, NPCs give rise to neuroblasts (NBs) (type A cells) or oligodendroblasts, which migrate through the rostral migratory stream to the olfactory bulb, where they become primarily interneurons, or to the adjacent corpus callosum, respectively (Kazanis et al., 2017). qNSCs are dormant, exhibit-delayed kinetics of neuron formation compared to aNSCs and retain their post-activation neurogenic potential even at the old age (Codega et al., 2014). In the mouse SEZ, they were initially thought to express CD133 (also known as prominin), along with ependymal 
cells, but later findings revealed that CD133 is expressed by both quiescent and activated NSCs (Codega et al., 2014). Nestin is an intermediate filament protein, widely considered to be a key NSC marker, both during development and in the adult brain (Imayoshi et al., 2011). In the SEZ, almost all of the dividing radial glia-like cells exhibit a dynamically regulated expression of Nestin; with qNSCs upregulating its expression (along with that of EGFR) upon activation in vitro, as well as during regeneration (Codega et al., 2014). These data are consistent with previous observations that Nestin/CD133+ cells are neurogenic in vivo and give rise to Nestin+ neurospheres in vitro (Coskun et al. ,2008). After transplantation of both qNSCs and aNSCs derived from the SEZ, Codega et al. (2014) reported oligodendrocyte formation suggesting that both populations are multipotent in vivo.
The full extent of SEZ NSC heterogeneity and the population dynamics of qNSCs and aNSCs, as well as their lineage relationships and their cytogenic potential, under homeostasis and during regeneration, is still unknown. Recent findings suggest that the process that starts with the activation of a qNSC and ends with the emergence of its progeny is a continuum, with rarely observed intermediate states, underlined by distinct molecular profiles (Dulken et al.,2017). Based on the levels of transcription and the expression of surface markers and key intracellular regulators, the NSC population can be divided into aNSC-early, aNSC-mid, and aNSC-late; the latter population is rich in cells with low GFAP expression (GFAP-GFPlow). Hence, FACS-driven selection of GFAP-GFPhigh-mid cells may allow for the isolation of the earliest, self-renewing NCS. The destiny of aNSCs that have given rise to NPCs is also uncertain. According

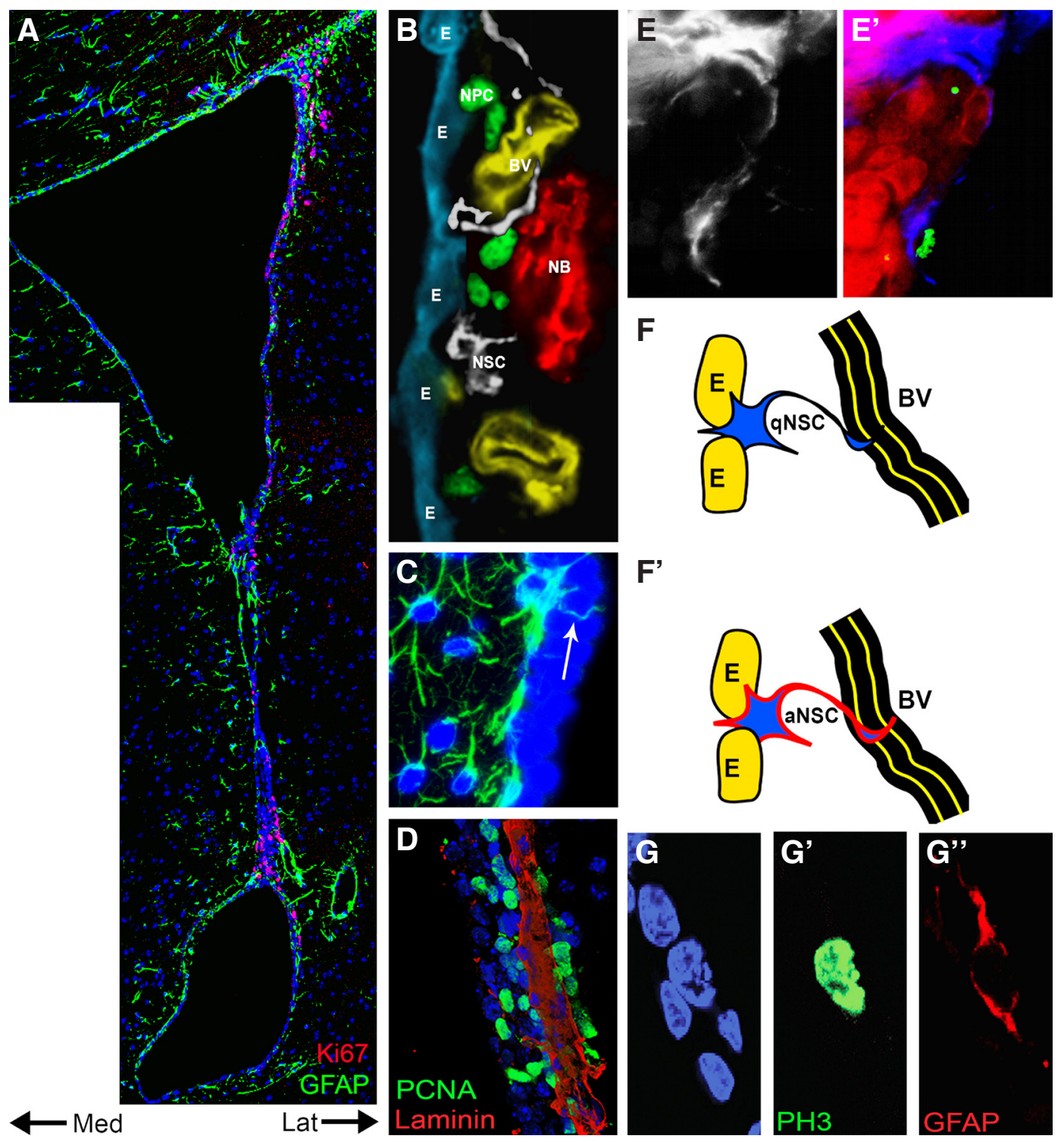

Fig. 1. Neural Stem and Progenitor cells located in the Subependymal Zone. (A)A low magnification photo of the lateral ventricle area, after immunohistochemical staining for Ki67 (in red, to mark proliferating cells) and GFAP (in green, to mark astrocytes). Note the abundance of $\mathrm{Ki} 67+$ cells at the lateral wall of the ventricle, where the main corpus of the niche is situated, as opposed to the medial wall. (B) Collage of real images of the main elements of the SEZ cytoarchitecture [E: S100 $\beta+$ ependymal cells; BV: laminin+ blood vessels; NSC: GFAP+ neural stem cells; NPC: Ascl1+ neural progenitor cells; NB: Doublecortin (DcX)+ clusters of neuroblasts. The scales are proportional]. (C) High magnification detail of the SEZ after immunostaining for GFAP (in green). Thearrow indicates a GFAP+ process intercalating throughependymal cells to reach the ventricle. (D) Fragment of the SEZ after immunostaining for PCNA (in green, to mark proliferating cells) and laminin (in red, to markblood vessels). Note the distribution of proliferating NPCs in close proximity to the blood vessel. (E) Detail of a BrdU-retaining cell in the SEZ, as identified by immunohistochemical staining for GFAP (In whiteand blue), integrin- $\beta 1$ (in red) and $\mathrm{BrdU}$ (in green), 30 days post BrdU administration. Note that the BrdU-retaining cells do not express integrin- $\beta 1$. (F) Schematic illustration of the typical position of a qNSC, adjacent to ependymal cells, tasting the CSF via an apical process and in direct contact with a blood vessel, via a basal process

Transition to the aNSC state is correlated with upregulation of membrane expression of EGFR and of integrin- $\beta 1$ (indicated by the red thick lining). (G) Detail, in high magnification of a rare radial glial-like GFAP+ cell, co-expressing PH3, next to ependymal cells, most probably one aNSC. The Figure is an adaptation of previously published figures. [(A, E) (Kazanis et al., 2010); (B) (Kazanis, 2013); (C) (Kazanis, 2009); (D) (Koutsakis and Kazanis, 2016); (F) (Kazanis and ffrench-Constant, 2011); (G)(Kazanis and ffrench-Constant, 2012)] 
to the canonical pathway, after a self-renewing (symmetric or asymmetric) division, the newly generated NSCs will reverse back to quiescence, with more similar cycles repeated throughout the life span of the organism. However, recent experimental work with in vivo cell fate mapping of NSCs has shown that aNSCs generate clones and then become exhausted (Calzolari et al., 2015), with only $20 \%$ undergoing self-renewing divisions (Obernier et al., 2018). This indicates that neurogenesis in the SEZ is reliant upon a tightly organized mobilization of qNSCs that are largely expendable, and this might explain the gradual decline in the cytogenic capacity of the SEZ (after 18 months in both rodents and humans) (Luo et al., 2006; Sanai et al., 2011) and its premature exhaustion upon the induced exit from quiescence (more details in the following section).

\section{Regulation of quiescence in NSCs}

Within the highly complex microenvironment of the SEZ, quiescence and activation of NSC is regulated by a range of local or remote, diffusible or contact-related signals. Ependymal cells and blood vessels constitute two key elements of the niche (Mirzadeh et al., 2008; Shen et al., 2008) and several reports indicate that quiescence is an actively maintained state, with qNSCs and their activated counterparts exhibiting different transcriptional profiles. Hallmarks of neural stem and progenitor cells, such as the transcription factors DIx1, DIx2, Sox4, Sox11, and Ascl1, are primarily expressed by aNSCs. In contrast, qNSCs express high levels of factors such as Vcam1 and ID3 (Codega et al., 2014; Dulken et al., 2017). Direct NSC-to-endothelium contact suppresses cell-cycle entry, via ephrinB2 and Jagged1, with endothelial-specific knockout of either of the genes aberrantly activating qNSCs and resulting in depletion of their pool (Ottone et al., 2014). From the ventricular side of the niche, functional ligands of $\mathrm{G}$ protein-coupled receptors, such as Sphingosine-1-phosphate receptor and Prostagladin2, both present in the cerebrospinal fluid (CSF) (Kondabolu et al., 2011), inhibit the activation of qNSCs (Codega et al., 2014). Moreover, the CSF supplies the SEZ, in an age-dependent manner, both with pro-quiescence factors, such as Neurotrophin3 or Platelet-Derived Growth Factor-D, and activating signals, such as Insulin-like Growth Factor-2 (Delgado et al., 2014; Silva-Vargas et al., 2016; Delgado et al., 2021). The in vitro culture of NSCs, isolated from live rats using the method of milking the SEZ, revealed the separate regulation of self-renewal and of exit from quiescence, since choroid plexus-conditioned media significantly enhanced the latter and at the same time significantly decreased the former (McClenahan et al., 2021). Interestingly, NT3 is acting on NSCs from both the CSF and blood vessels.

Notch2 (but not Notch1) signaling also conveys quiescence to SEZ NSCs by repressing cell-cycle related genes and neurogenesis. Loss of Notch2 activates qNSCs, which proliferate and generate new neurons. Notch2 deficiency results in accelerated SEZ NSC exhaustion and an ageing-like phenotype. Simultaneous loss of Notch1 and Notch2 resembled the total loss of Rbpj-mediated canonical Notch signaling; thus, Notch2 functions are not compensated in NSCs, and Notch2 is indispensable for the maintenance of NSC quiescence in the SEZ (Engler et al., 2018). BMP4 has also been identified as a pro-quiescence factor (Marqués-Torrejón et al., 2021), while deregulation of Sonic Hedgehog (Shh) signaling can also lead to disrupted quiescence and exhaustion of neurogenesis (Petrova et al., 2013; Daynac et al., 2016b).
Maintaining a healthy proteome throughout life is critical for proper somatic stem cell function and is regulated by several processes; however, the complexities of the stem cell response to increases in damaged or aggregated proteins remain unclear. Recent studies have shown that qNSCs of the SEZ have increased levels of protein aggregates (proteostasis), which are removed through autophagy as soon as they transit in mitotic activation. Induction of autophagy enhanced clearance of these aggregated proteins and increased the rate of qNSC activation (Leeman et al., 2018). The initiation of expression of vimentin, which is an intermediate filament protein that acts as a spatial coordinator of proteasomes to the aggresome, has been shown to be an early sign of primed qNSCs. In qNSCs, vimentin expression is repressed, and cells do not form vimentin cages in the presence of increased protein aggregates. Once activated, though, NSCs need to process aggregated proteins, and vimentin's function at the aggresome is to organize proteostasis-related proteins. In the absence of vimentin, NSCs have a reduced capacity to exit quiescence and exhibit an early, progressive decline in proliferation and neurogenesis (Morrow et al., 2020). An alternative process involves the storage of protein aggregates in large lysosomes, in qNSCs of young mice. qNSCs contain numerous large lysosomes, fused with autophagosomes to form autolysosomes, but with their content not yet degraded. Perturbation of this lysosomal activity affected the ability of qNSCs to become activated. In line with these observations, aNSCs exhibited increased expression of proteasome-associated genes, while qNSCs had increased expression of lysosome-associated genes (Leeman et al., 2018). Treatment with bafilomycin A, which blocks lysosomal acidification, or nutrient deprivation, led to decreased NSC activation in response to growth factors and did not affect proliferation of qNSCs (Leeman et al., 2018).

\section{qNSCs and aNSCs in the ageing SEZ}

Recent studies report a dramatic drop in NSC numbers in the ageing murine brain. Either a rapid decline from two to seven months, which decelerates thereafter (Kalamakis et al., 2019), or a more delayed decline, that becomes abrupt after 18 months (Delgado et al., 2021). The remaining stem cell reservoir is protected from full depletion by an increase in quiescence. Notably, aged NSCs remain capable of regenerating the injured brain (albeit, with lower speed) (Kalamakis et al., 2019), supported by a higher proliferation capacity of their daughter NPCs (Luo et al., 2006). In the aged brain, NSCs also retain the ability to generate the different subtypes of olfactory bulb interneurons, albeit at much lower numbers (Llorens-Bobadilla et al., 2015; Dulken et al., 2017; Obernier et al., 2018). The transcriptional profile of NSCs of different ages remains largely similar. It also indicates that young NSCs transit smoothly between the quiescent and primed-quiescent states, readily followed by activation; while aged NSCs remain primarily in the quiescent state and fewer of them enter the aNSC state to become fully activated (Kalamakis et al., 2019). During ageing, aNSCs require progressively more time to complete their cell cycle, and the time NSCs spend in quiescence increases (Daynac et al., 2016a). In their recent work, Kalamakis et al. (2019)-based on gene expression patterns- proposed a hierarchical clustering for lineage progression from qNSCs1 / qNSCs2 / aNSCs0 / aNSCs1 / aNSCs2 / TAPs / NBs for old and young NSCs. They also demonstrated that the increased number of cells within the qNSC1 cluster in the 
aged SEZ is not due to contaminating astrocytes but to a higher number of bona-fide qNSCs1. A decline in the proteome's health is also associated with ageing and neurodegenerative diseases, with aged qNSCs exhibiting defects in their lysosomes and increased accumulation of protein aggregates. Enhancement of the lysosome pathway cleared protein aggregates and increased the ability of aged qNSCs to become activated; overall, this allows them to regain a more youthful behavior (Leeman et al., 2018).

Besides any cell-autonomous changes, which seem to be minimal, exogenous parameters influence the ageing of NSCs. Activation of an interferon (INF) y response is required to increase activation of young NSCs upon injury (Llorens-Bobadilla et al., 2015) and INFs derived from the choroid plexus impact negatively on hippocampal neurogenesis in the aged brain (Baruch et al., 2014). Thus, neutralizing inflammation might level off the age-related decline in activation of NSCs in the aged SEZ. Furthermore, endothelial cells exhibit the highest age-related changes among the different cell types of the SEZ (Kalamakis et al., 2019), and the effect of choroid plexus factors on the activation of NSCs changes from inducing to repressing with ageing (Silva-Vargas et al., 2016).

\section{In vitro behavior of SEZ-derived qNSCs}

Since the early studies on the discovery of quiescent stem cells, our understanding of the mechanisms that cells use to enter, maintain, and exit quiescence has increased dramatically. This has been accomplished primarily by modeling cellular quiescence in in vitro culture systems using multiple approaches (van Velthoven and Rando, 2019). Quiescence of cells in vitro can be induced by subjecting cells to a variety of quiescence-promoting conditions, including mitogen deprivation, nutrient starvation, contact inhibition, and adhesion deprivation.

Isolated tissue-specific stem cells are usually grown in conditions that promote exit from quiescence and maintenance of mitotic activity, possibly because culture media are typically chosen on the evidence of enhanced colony formation. (Coller et al., 2006). Importantly, though, in intestinal organoid assays, stem cells were seen to exhibit their full differentiation potential only when cultured in conditions that allow them to enter quiescence (Basak et al., 2017). In the case of NSCs, the standard in vitro assay is that of neurosphere formation (generation of 3-Dimensional, freefloating, aggregates that can be passaged and differentiated). The neurosphere assay is the established readout of the presence of NSCs in a tissue, and it was originally sugggested that qNSCs give rise to neurospheres (Morshead et al., 1994). However, recent work indicated that qNSCs rarely form neurospheres or give rise to adherent cell colonies (Codega et al., 2014), and that sphereforming assays predominantly depend on the expansion of cells that are either poised for proliferation in vivo or are already actively dividing, such as GFAP+ aNSCs and EGFR+GFAP- NPCs (Doetsch et al., 2002). A recent, very detailed, study (Codega et al., 2014) revealed that isolated qNSCs and aNSCs can interconvert, with each population giving rise to the other populations in vitro. Initially, plated qNSCs are small and round and do not express Nestin, EGFR, or MCM2. As they become activated, they undergo morphological and molecular changes, enlarging their nuclei and extending processes, closely resembling cultured aNSCs. qNSCs only rarely give rise to colonies, and do so with much slower growth kinetics than aNSCs. Importantly, although rare, the colonies formed by single qNSCs are large and multipotent, giving rise to neurons, oligodendrocytes, and mature astrocytes. The proliferation of the qNSC population is generally delayed by 6-10 days compared with aNSCs; however, once activated, they exhibited similar rates of division to aNSCs. Regarding primitive and definitive NSCs, the first generate multipotent clones only in the presence of leukemia inhibitory factor and can also give rise to the latter, which are the typical epidermal growth factor (EGF) / fibroblast growth factor (FGF)-2 responding cells (Sachewsky et al., 2019). BMPs have been implicated as regulators of quiescence in a variety of different adult stem cell systems including the brain, hair follicle, intestine, bone marrow. BMPs induce quiescence in the hippocampal stem cell niche and, in cooperation with FGF-2 signaling, suppress terminal astrocytic differentiation and maintain stem cell potency during the quiescence state. Recently, Marqués-Torrejón et al. (2021), used modified in vitro NSC culture conditions, including either low concentration BMPs, or BMP/FGF2, and identified two distinct quiescent NSC states. In the absence of exogenous FGF2, BMP signalling induces a deep, or dormant, quiescent state; however, when BMP and FGF2 are combined, a distinct primed quiescent state emerges with cells readily available to re-enter cell cycle. Furthermore, they identified LRIG1 as an important regulator of the primed quiescent NSC state. LRIG1 is required to maintain the quiescence state, avoiding awakening quiescent NSCs, most likely through EGFR signalling.

\section{Latent NSCs (laNSCs) outside a niche}

The existence of cells with a latent neurogenic potential in the parenchyma is all the more investigated, especially after it was clearly shown that postnatal NSCs have the morphology of astrocytes. The existence of such cells, dispersed throughout the parenchyma of the brain, even though is not normally sufficient for brain repair, offers an alternative therapeutic target. This field has attracted more interest in recent years due to the emergence of direct cell-reprogramming technology.

\section{Cortex}

Even though there is no evidence of postnatal neurogenesis in the cerebral cortex, the first report of parenchymal astrocytes with neurogenic potential in vitro was provided after a cortical stab injury (Buffo et al., 2008) and in astrocytes isolated from the healthy cortex after Shh administration (Sirko et al., 2013). After stab wound injury, fate-mapping analysis of mature astrocytes showed that they convert to reactive astrocytes that can form self-renewing neurospheres and differentiate to both neuronal and glial lineages in vitro; however, in vivo they remain restricted to the astroglial lineage (Buffo et al., 2008). The question of the origin of these progenitors "in wait" (local or niche-derived) is still open, with at least one team having reported the contribution of the SEZ niche (Faiz et al., 2015). A recently study showed that following stab wound injury, cortical astrocytes are able to initiate a latent neurogenic program only after Notch-signaling inhibition. The progeny of these astrocytes was Ascl1+ NPCs and Dcx+ neuroblasts and, eventually, NeuN+ neurons (Zamboni et al., 2020).

The technology of generating induced pluripotent stem cells has been intensively modulated in order to enable the in vivo reprogramming of endogenous cells, almost exclusively astrocytes 
in the brain, towards the neuronal fate. After a stab-wound injury to the whole neocortical column, including both the grey and white matter, the overexpression of $\mathrm{Ngn} 2$ and Nurr1, specifically in astrocytes located close to the lesion, led to the emergence of newborn neurons only in the grey matter. These originated from both proliferative and quiescent astrocytes with properties typical for their position along the cortical column: morphology, immunoreactivity for region-specific markers, electrophysiological properties, connectivity, and long-distance axon projections (Mattugini et al., 2019). Chemical reprogramming of both cortical and striatal astrocytes to neurons was reported after administration of the FICBY cocktail (Forskolin, ISX9, CHIR99021, I-BET151, and Y-27632). The chemically induced neurons expressed regionspecific neuronal markers and were able to form synapses with endogenous neurons (Ma et al., 2021).

\section{Striatum}

No postnatal striatal neurogenesis has been observed in mice under physiological conditions (Magnusson et al., 2014; Nato et al., 2015); after injury, however, striatal astrocytes function as local NPCs, giving rise to new neurons. Magnusson et al. (2014) were able to selectively label striatal astrocytes, excluding those of the neighboring SEZ, and reported that after inducing stroke, striatal astrocytes generated Ascl1+ NPCs and Dcx+ neuroblasts that differentiated to mature neurons (NeuN+ cells), some becoming GABAergic interneurons (nNOS+ cells). Stroke activated the latent neurogenic potential of local astrocytes via the reduction of Notch1 signaling. Nato et al. (2015) used the quinolinic acid lesion mouse model of Huntington's disease and observed a similar response. Fate-mapping analysis showed that striatal astrocytes became proliferative (Ki67+) after the lesion and gave rise to Ascl1+ NPCs and $\mathrm{Dcx}+$ neuroblasts that differentiated to $\mathrm{NeuN}+$ neurons. In the postnatal rat striatum, new GABAergic neurons were shown to be generated under physiological conditions (Dayer et al., 2005). Moreover, after a transient middle cerebral artery occlusion (MCAO) ischemic injury, astrocytes became reactive and expressed the neural stem / progenitor cell markers Nestin, Pax6, and Sox2. These astrocytes differentiated towards a neuronal lineage, expressing both immature (Tuj1) and mature (NeuN or Map2) neuronal markers, with these neurons maturing into cholinergic or GABAergic neurons that were morphologically and electrochemically similar to pre-existing neurons (Duan et al., 2015). Using the same MCAO rat model, another study reported enhanced transdifferentiation of reactive astrocytes into mature neurons after overexpression of vascular endothelial growth factor (VEGF) in the reactive astrocytes (Shen et al., 2016). Importantly, in the human striatum, new interneurons are continuously being generated, as was revealed by IdU labeling and a ${ }^{14} \mathrm{C}$ dating approach, with this local endogenous process being perturbed in patients with Huntington's disease (Ernst et al., 2014).

Striatal astrocytes have been targeted for reprogramming (Ma et al., 2021), more intensively in the context of Parkinson's disease (PD). In the 6-hydroxydopamine (6-OHDA) model of PD, overexpression of the transcription factors NeuroD1, Ascl1 and LmX1A, and of the microRNA218, resulted in the generation of mature dopaminergic $(\mathrm{TH}+)$ neurons (DNs), expressing typical transcription factors of the dopaminergic lineage. Functionally, the induced DNs could take up and release dopamine, generating action potential and improved motor behavior (Rivetti di Val Cervo et al., 2017). In another study, using the same model of PD, striatal astrocytes were converted to DNs by CasRx-mediated knockdown of the Ptbp 1 gene, resulting in the generation of functional $\mathrm{TH}+$ neurons that improved the motor dysfunctions (Zhou et al., 2020).

\section{Substantia nigra (SN)}

Postnatal neurogenesis in the SN remains controversial. A few research groups have reported the detection of adult-born DNs in healthy mice and rats (Van Kampen and Robertson, 2005; Shan et al., 2006; Xie et al., 2017) and a few others have failed to reproduce these results (Mao et al., 2001; Morrison, 2016). Similarly, contradictory results have been reported for the induction of dopaminergic neurogenesis in the $\mathrm{SN}$ in chemotoxic parkinsonian rodent models, such as 6-OHDA and MPTP (Lie et al., 2002; Mohapel et al., 2005). Our group recently reported the existence of local neurogenesis in both healthy and degenerated SN. Notably, we found that although new DNs were generated locally in the SN, SEZ-derived NPCs contributed to this process (Lie et al., 2002; Mourtzi et al., 2021). In another study, a pool of NPCs (BrdU+ cells) with gliogenic potential has been detected in the SN, with these cells exhibiting neurogenic potential after transplantation in the hippocampus (Lie et al., 2002).

Recently, SN astrocytes were successfully reprogrammed to DNs by knocking down Ptbp1. Induced DNs, as assessed by chemogenetic analysis, were responsible for restoring the striatal dopamine levels and for improving motor behavior. Importantly, it was shown that reprogrammed astrocytes exhibited regional specificity (Qian et al., 2020).

\section{Acknowledgments}

DD and DK were supported by a Fondation Santé grant to IK.

\section{References}

BARUCH K., DECZKOWSKA A., DAVID E., CASTELLANO J. M., MILLER O., KERTSER A., BERKUTZKI T., BARNETT-ITZHAKI Z., BEZALEL D., WYSS-CORAY T., AMIT I., SCHWARTZ M. (2014). Aging-induced type I interferon response at the choroid plexus negatively affects brain function. Science 346: 89-93. https://doi. org/10.1126/science. 1252945

BUTTGEREIT F., BRAND M. D. (1995). A hierarchy of ATP-consuming processes in mammalian cells. Biochemical Journal 312: 163-167. https://doi.org/10.1042/ bj3120163

CALZOLARI F., MICHEL J., BAUMGARTE. V., THEIS F., GÖTZ M., NINKOVIC J. (2015) Fast clonal expansion and limited neural stem cell self-renewal in the adult subependymal zone. Nature Neuroscience 18:490-492. https://doi.org/10.1038/nn.3963

CODEGA P., SILVA-VARGAS V., PAUL A., MALDONADO-SOTO A. R., DELEO A. M., PASTRANA E., DOETSCH F. (2014). Prospective Identification and Purification of Quiescent Adult Neural Stem Cells from Their In Vivo Niche. Neuron 82: 545-559. https://doi.org/10.1016/j.neuron.2014.02.039

COLLER H. A., SANG L., ROBERTS J. M. (2006). A New Description of Cellular Quiescence. PLoS Biology 4: e83. https://doi.org/10.1371/journal.pbio.0040083

COSKUN V., WU H., BLANCHI B., TSAO S., KIM K., ZHAO J., BIANCOTTI J. C., HUTNICK L., KRUEGER R. C., FAN G., DE VELLIS J., SUN Y. E. (2008). CD133 + neural stem cells in the ependyma of mammalian postnatal forebrain. Proceedings of the National Academy of Sciences 105: 1026-1031. https://doi.org/10.1073/ pnas. 0710000105

DAYER A. G., CLEAVER K. M., ABOUANTOUN T., CAMERON H. A. (2005). New GABAergic interneurons in the adult neocortex and striatum are generated from different precursors. Journal of Cell Biology 168: 415-427. https://doi.org/10.1083/ jcb.200407053 
DAYNAC M., MORIZUR L., CHICHEPORTICHE A., MOUTHON M.A., BOUSSIN F. D. (2016a). Age-related neurogenesis decline in the subventricular zone is associated with specific cell cycle regulation changes in activated neural stem cells. Scientific Reports 6: 21505. https://doi.org/10.1038/srep21505

DAYNAC M., TIROU L., FAURE H., MOUTHON M.A., GAUTHIER L. R., HAHN H., BOUSSIN F. D., RUAT M. (2016b). Hedgehog Controls Quiescence and Activation of Neural Stem Cells in the Adult Ventricular-Subventricular Zone. Stem Cell Reports 7: 735-748. https://doi.org/10.1016/j.stemcr.2016.08.016

DELGADO A. C., FERRÓN S. R., VICENTE D., PORLAN E., PEREZ-VILLALBA A., TRUJILLO C. M., D'OCÓN P., FARIÑAS I. (2014). Endothelial NT-3 Delivered by Vasculature and CSF Promotes Quiescence of Subependymal Neural Stem Cells through Nitric Oxide Induction. Neuron 83: 572-585. https://doi.org/10.1016/j. neuron.2014.06.015

DELGADO A. C., MALDONADO-SOTO A. R., SILVA-VARGAS V., MIZRAK D., VON KÄNEL T., TAN K. R., PAUL A., MADAR A., CUERVO H., KITAJEWSKI J., LIN C.S., DOETSCH F. (2021). Release of stem cells from quiescence reveals gliogenic domains in the adult mouse brain. Science 372: 1205-1209. https://doi. org/10.1126/science.abg8467

DOETSCH F., PETREANU L., CAILLEI., GARCIA-VERDUGO J.M., ALVAREZ-BUYLLA A. (2002). EGF Converts Transit-Amplifying Neurogenic Precursors in the Adult Brain into Multipotent Stem Cells. Neuron 36:1021-1034. https://doi.org/10.1016/ S0896-6273(02)01133-9

DUAN C.L., LIU C.W., SHEN S.W., YUZ., MO J.L., CHEN X.H., SUN F.Y. (2015). Striatal astrocytes transdifferentiate into functional mature neurons following ischemic brain injury. Glia 63: 1660-1670. https://doi.org/10.1002/glia.22837

DULKEN B. W., LEEMAN D. S., BOUTET S. C., HEBESTREIT K., BRUNET A. (2017). Single-Cell Transcriptomic Analysis Defines Heterogeneity and Transcriptional Dynamics in the Adult Neural Stem Cell Lineage. Cell Reports 18: 777-790. https:// doi.org/10.1016/j.celrep.2016.12.060

ENGLER A., ROLANDO C., GIACHINO C., SAOTOME I., ERNI A., BRIEN C., ZHANG R., ZIMBER-STROBL U., RADTKE F., ARTAVANIS-TSAKONAS S., LOUVI A., TAYLOR V. (2018). Notch2 Signaling Maintains NSC Quiescence in the Murine Ventricular-Subventricular Zone. Cell Reports 22: 992-1002. https://doi. org/10.1016/j.celrep.2017.12.094

ERNST A., ALKASS K., BERNARD S., SALEHPOUR M., PERL S., TISDALE J., POSSNERT G., DRUID H., FRISÉN J. (2014). Neurogenesis in the Striatum of the Adult Human Brain. Cell 156: 1072-1083. https://doi.org/10.1016/j.cell.2014.01.044

FAIZ M., SACHEWSKY N., GASCÓN S., BANG K.W. A., MORSHEAD C. M., NAGY A. (2015). Adult Neural Stem Cells from the Subventricular Zone Give Rise to Reactive Astrocytes in the Cortex after Stroke. Cell Stem Cell 17: 624-634. https://doi. org/10.1016/j.stem.2015.08.002

HACK M. A., SAGHATELYAN A., DE CHEVIGNY A., PFEIFER A., ASHERY-PADAN R., LLEDO P.M., GÖTZ M. (2005). Neuronal fate determinants of adult olfactory bulb neurogenesis. Nature Neuroscience 8: 865-872. https://doi.org/10.1038/nn1479

IMAYOSHI I., SAKAMOTO M., KAGEYAMA R. (2011). Genetic Methods to Identify and Manipulate Newly Born Neurons in the Adult Brain. Frontiers in Neuroscience 5: 64. https://doi.org/10.3389/fnins.2011.00064

IMURA T., KORNBLUM H. I., SOFRONIEW M. V. (2003). The Predominant Neural Stem Cell Isolated from Postnatal and Adult Forebrain But Not Early Embryonic Forebrain Expresses GFAP. The Journal of Neuroscience 23: 2824-2832. https:// doi.org/10.1523/JNEUROSCI.23-07-02824.2003

KALAMAKIS G., BRÜNE D., RAVICHANDRAN S., BOLZ J., FAN W., ZIEBELL F., STIEHL T., CATALÁ-MARTINEZ F., KUPKE J., ZHAO S., LLORENS-BOBADILLA E., BAUER K., LIMPERT S., BERGER B., CHRISTEN U., SCHMEZER P., MALLM J. P., BERNINGER B., ANDERS S., DEL SOL A., MARCINIAK-CZOCHRA A., MARTIN-VILLALBA A. (2019). Quiescence Modulates Stem Cell Maintenance and Regenerative Capacity in the Aging Brain. Cell 176: 1407-1419.e14. https:// doi.org/10.1016/j.cell.2019.01.040

KAZANIS I. (2009). The subependymal zone neurogenic niche: a beating heart in the centre of the brain: How plastic is adult neurogenesis? Opportunities for therapy and questions to be addressed. Brain 132: 2909-2921. https://doi.org/10.1093/ brain/awp237

KAZANIS I., LATHIA J. D., VADAKKAN T. J., RABORN E., WAN R., MUGHAL M. R., ECKLEYD. M., SASAKIT., PATTON B., MATTSON M.P., HIRSCHIK. K., DICKINSON M. E., FFRENCH-CONSTANT C. (2010). Quiescence and Activation of Stem and Precursor Cell Populations in the Subependymal Zone of the Mammalian Brain Are Associated with Distinct Cellular and Extracellular Matrix Signals. Journal of Neuroscience 30: 9771-9781. https://doi.org/10.1523/JNEUROSCI.0700-10.2010
KAZANISI.,FFRENCH-CONSTANTC. (2011). Extracellular matrix and the neural stem cell niche. Developmental Neurobiology 71: 1006-1017. https://doi.org/10.1002/ dneu.20970

KAZANIS I., FFRENCH-CONSTANT C. (2012). The Number of Stem Cells in the Subependymal Zone of the Adult Rodent Brain is Correlated with the Number of Ependymal Cells and Not with the Volume of the Niche. Stem Cells and Development 21: 1090-1096. https://doi.org/10.1089/scd.2011.0130

KAZANIS I. (2013). Neurogenesis in the Adult Mammalian Brain: How Much Do We Need, How Much Do We Have? In Neurogenesis and Neural Plasticity (Ed. Belzung C., Wigmore P.). Current Topics in Behavioral Neurosciences, Vol. 15. Springer Berlin Heidelberg, Berlin, Heidelberg, pp. 3-29. https://doi.org/10.1007/7854_2012_227

KAZANIS I., EVANS K. A., ANDREOPOULOU E., DIMITRIOU C., KOUTSAKIS C., KARADOTTIR R. T., FRANKLIN R. J.M. (2017). Subependymal Zone-Derived Oligodendroblasts Respond to Focal Demyelination but Fail to Generate Myelin in Young and Aged Mice. Stem Cell Reports 8: 685-700. https://doi.org/10.1016/j. stemcr.2017.01.007

KONDABOLU S., ADSUMELLI R., SCHABEL J., GLASS P., PENTYALA S. (2011). Evaluation of prostaglandin D2 as a CSF leak marker: implications in safe epidural anesthesia. Local and Regional Anesthesia 4:21-24. https://doi.org/10.2147/LRA.S18053

KOUTSAKIS C., KAZANIS I. (2016). How Necessary is the Vasculature in the Life of Neural Stem and Progenitor Cells? Evidence from Evolution, Development and the Adult Nervous System. Frontiers in Cellular Neuroscience 10: 35. https://doi. org/10.3389/fncel.2016.00035

LEEMAN D. S., HEBESTREIT K., RUETZ T., WEBB A. E., MCKAY A., POLLINA E. A., DULKEN B. W., ZHAO X., YEO R. W., HO T. T., MAHMOUDI S., DEVARAJAN K., PASSEGUÉ E., RANDO T. A., FRYDMAN J., BRUNET A. (2018). Lysosome activation clears aggregates and enhances quiescent neural stem cell activation during aging. Science 359: 1277-1283. https://doi.org/10.1126/science.aag3048

LIE D. C., DZIEWCZAPOLSKI G., WILLHOITE A. R., KASPAR B. K., SHULTS C. W., GAGE F. H. (2002). The Adult Substantia Nigra Contains Progenitor Cells with Neurogenic Potential. The Journal of Neuroscience 22: 6639-6649. https://doi. org/10.1523/JNEUROSCI.22-15-06639.2002

LLORENS-BOBADILLA E., ZHAO S., BASER A., SAIZ-CASTRO G., ZWADLO K., MARTIN-VILLALBA A. (2015). Single-Cell Transcriptomics Reveals a Population of Dormant Neural Stem Cells that Become Activated upon Brain Injury. Cell Stem Cell 17: 329-340. https://doi.org/10.1016/j.stem.2015.07.002

LUGERT S., BASAK O., KNUCKLES P., HAUSSLER U., FABEL K., GÖTZ M., HAAS C. A., KEMPERMANN G., TAYLOR V., GIACHINO C. (2010). Quiescent and Active Hippocampal Neural Stem Cells with Distinct Morphologies Respond Selectively to Physiological and Pathological Stimuli and Aging. Cell Stem Cell 6: 445-456. https://doi.org/10.1016/j.stem.2010.03.017

LUO J., DANIELS S. B., LENNINGTON J. B., NOTTI R. Q., CONOVER J. C. (2006). The aging neurogenic subventricular zone. Aging Cell 5: 139-152. https://doi. org/10.1111/j.1474-9726.2006.00197.x

MA Y., XIE H., DU X., WANG L., JIN X., ZHANG Q., HAN Y., SUN S., WANG L., LI X., ZHANG C., WANG M., LI C., XU J., HUANG Z., WANG X., CHAI Z., DENG H. (2021). In vivo chemical reprogramming of astrocytes into neurons. Cell Discovery 7: 12. https://doi.org/10.1038/s41421-021-00243-8

MAGNUSSON J. P., GÖRITZ C., TATARISHVILI J., DIAS D. O., SMITH E. M. K., LINDVALL O., KOKAIA Z., FRISÉN J. (2014). A latent neurogenic program in astrocytes regulated by Notch signaling in the mouse. Science 346: 237-241. https://doi.org/10.1126/science.346.6206.237

MAO L., LAU Y.S., PETROSKE E., WANG J. Q. (2001). Profound astrogenesis in the striatum of adult mice following nigrostriatal dopaminergic lesion by repeated MPTP administration. Developmental Brain Research 131: 57-65. https://doi. org/10.1016/S0165-3806(01)00260-7

MARQUÉS-TORREJÓN M. , WILLIAMS C. A. C., SOUTHGATE B., ALFAZEMA N., CLEMENTS M. P., GARCIA-DIAZ C., BLIN C., ARRANZ-EMPARAN N., FRASER J., GAMMOH N., PARRINELLO S., POLLARD S. M. (2021). LRIG1 is a gatekeeper to exit from quiescence in adult neural stem cells. Nature Communications 12: 2594. https://doi.org/10.1038/s41467-021-22813-w

MASLOV A. Y., BAILEY K. J., MIELNICKI L. M., FREELAND A. L., SUN X., BURHANS W. C., PRUITT S. C. (2007). Stem/Progenitor Cell-Specific Enhanced Green Fluorescent Protein Expression Driven by the Endogenous Mcm2 Promoter. Stem Cells 25: 132-138. https://doi.org/10.1634/stemcells.2006-0032

MATTUGINI N., BOCCHI R., SCHEUSS V., RUSSO G. L., TORPER O., LAO C. L., GÖTZ M. (2019). Inducing Different Neuronal Subtypes from Astrocytes in the Injured Mouse Cerebral Cortex. Neuron 103: 1086-1095.e5. https://doi.org/10.1016/j. neuron.2019.08.009 
MCCLENAHAN F., DIMITRIOU C., KOUTSAKIS C., DIMITRAKOPOULOS D., ARAMPATZIS A., KAKOURI P., KOURLA M., OIKONOMOU S., ANDREOPOULOU E., PATSONIS M., MERI D.K., RASOOL R.T., FRANKLIN R. J.M., KAZANIS I. (2021). Isolation of neural stem and oligodendrocyte progenitor cells from the brain of live rats. Stem Cell Reports 16: 2534-2547. https://doi.org/10.1016/j. stemcr.2021.08.015

MIRZADEH Z., MERKLE F. T., SORIANO-NAVARRO M., GARCIA-VERDUGO J. M. ALVAREZ-BUYLLA A. (2008). Neural Stem Cells Confer Unique Pinwheel Architecture to the Ventricular Surface in Neurogenic Regions of the Adult Brain. Cell Stem Cell 3: 265-278. https://doi.org/10.1016/j.stem.2008.07.004

MOHAPEL P., FRIELINGSDORF H., HÄGGBLAD J., ZACHRISSON O., BRUNDIN P. (2005). Platelet-Derived Growth Factor (PDGF-BB) and Brain-Derived Neurotrophic Factor (BDNF) induce striatal neurogenesis in adult rats with 6-hydroxydopamine lesions. Neuroscience 132: 767-776. https://doi.org/10.1016/j.neuroscience.2004.11.056

MORRISON B.E. (2016). Discovery of nigral dopaminergic neurogenesis in adult mice. Neural Regeneration Research 11: 0. https://doi.org/10.4103/1673-5374.184449

MORROW C. S., PORTER T. J., XU N., ARNDT Z. P., AKO-ASARE K., HEO H. J., THOMPSON E. A.N., MOORE D. L. (2020). Vimentin Coordinates Protein Turnover at the Aggresome during Neural Stem Cell Quiescence Exit. Cell Stem Cell 26: 558-568.e9. https://doi.org/10.1016/j.stem.2020.01.018

MORSHEAD C. M., REYNOLDS B. A., CRAIG C. G., MCBURNEY M. W., STAINES W. A., MORASSUTTI D., WEISS S., VAN DER KOOY D. (1994). Neural stem cells in the adult mammalian forebrain: A relatively quiescent subpopulation of subependymal cells. Neuron 13: 1071-1082. https://doi.org/10.1016/0896-6273(94)90046-9

MOURTZI T., DIMITRAKOPOULOS D., KAKOGIANNIS D., SALODIMITRIS C., BOTSAKIS K., MERI D. K., ANESTI M., DIMOPOULOU A., CHARALAMPOPOULOS I., GRAVANIS A., MATSOKIS N., ANGELATOU F., KAZANISI. (2021). Characterization of substantia nigra neurogenesis in homeostasis and dopaminergic degeneration: beneficial effects of the microneurotrophin BNN-20. Stem Cell Research \& Therapy 12: 335. https://doi.org/10.1186/s13287-021-02398-3

NATO G., CARAMELLO A., TROVAS., AVATANEO V., ROLANDO C., TAYLORV., BUFFO A., PERETTO P., LUZZATI F. (2015). Striatal astrocytes produce neuroblasts in an excitotoxic model of Huntington's disease. Development 142: 840-845. https:// doi.org/10.1242/dev.116657

OBERNIER K., CEBRIAN-SILLA A., THOMSON M., PARRAGUEZ J. I., ANDERSON R., GUINTO C., RODAS RODRIGUEZ J., GARCIA-VERDUGO J.M., ALVAREZBUYLLA A. (2018). Adult Neurogenesis Is Sustained by Symmetric Self-Renewal and Differentiation. Cell Stem Cell 22: 221-234.e8. https://doi.org/10.1016/j. stem.2018.01.003

OTTONE C., KRUSCHE B., WHITBY A., CLEMENTS M., QUADRATO G., PITULESCU M. E., ADAMS R. H., PARRINELLO S. (2014). Direct cell-cell contact with the vascular niche maintains quiescent neural stem cells. Nature Cell Biology 16: 1045-1056. https://doi.org/10.1038/ncb3045

PETROVA R., GARCIA A. D. R., JOYNER A. L. (2013). Titration of GLI3 Repressor Activity by Sonic Hedgehog Signaling Is Critical for Maintaining Multiple Adult Neural Stem Cell and Astrocyte Functions. Journal of Neuroscience 33: 1749017505. https://doi.org/10.1523/JNEUROSCI.2042-13.2013

QIAN H., KANG X., HU J., ZHANG D., LIANG Z., MENG F., ZHANG X., XUEY., MAIMON R., DOWDY S. F., DEVARAJ N. K., ZHOU Z., MOBLEY W. C., CLEVELAND D. W., FU X.D. (2020). Reversing a model of Parkinson's disease with in situ converted nigral neurons. Nature 582: 550-556. https://doi.org/10.1038/s41586-020-2388-4

RIVETTI DI VAL CERVO P., ROMANOV R. A., SPIGOLON G., MASINI D., MARTÍNMONTAÑEZ E., TOLEDO E. M., LA MANNO G., FEYDER M., PIFL C., NG Y.H., SÁNCHEZ S. P., LINNARSSON S., WERNIG M., HARKANY T., FISONE G., ARENAS E. (2017). Induction of functional dopamine neurons from human astrocytes in vitro and mouse astrocytes in a Parkinson's disease model. Nature Biotechnology 35: 444-452. https://doi.org/10.1038/nbt.3835
RODGERS J. T., KING K. Y., BRETT J. O., CROMIE M. J., CHARVILLE G. W., MAGUIRE K. K., BRUNSON C., MASTEY N., LIU L., TSAI C.R., GOODELL M. A., RANDO T. A. (2014). mTORC1 controls the adaptive transition of quiescent stem cells from G0 to GAlert. Nature 510: 393-396. https://doi.org/10.1038/nature13255

SANAI N., NGUYEN T., IHRIE R. A., MIRZADEH Z., TSAI H.H., WONG M., GUPTA N., BERGER M. S., HUANG E., GARCIA-VERDUGO J.M., ROWITCH D. H., ALVAREZ-BUYLLA A. (2011). Corridors of migrating neurons in the human brain and their decline during infancy. Nature 478: 382-386. https://doi.org/10.1038/ nature 10487

SHAN X., CHI L., BISHOP M., LUO C., LIEN L., ZHANG Z., LIU R. (2006). Enhanced De Novo Neurogenesis and Dopaminergic Neurogenesis in the Substantia Nigra of 1-Methyl-4-phyenyl-1,2,3,6-Tetrahydropyridine-Induced Parkinson's Disease-Like Mice. STEM CELLS 24:1280-1287. https://doi.org/10.1634/stemcells.2005-0487

SHEN Q., WANG Y., KOKOVAY E., LIN G., CHUANG S.M., GODERIE S. K., ROYSAM B., TEMPLE S. (2008). Adult SVZ Stem Cells Lie in a Vascular Niche: A Quantitative Analysis of Niche Cell-Cell Interactions. Cell Stem Cell 3: 289-300. https:// doi.org/10.1016/j.stem.2008.07.026

SHEN S.W., DUAN C.L., CHEN X.H., WANG Y.Q., SUN X., ZHANG Q.W., CUI H.R., SUN F.Y. (2016). Neurogenic effect of VEGF is related to increase of astrocytes transdifferentiation into new mature neurons in rat brains after stroke. Neuropharmacology 108: 451-461. https://doi.org/10.1016/j.neuropharm.2015.11.012

SILVA-VARGAS V., MALDONADO-SOTO A. R., MIZRAK D., CODEGA P., DOETSCH F. (2016). Age-Dependent Niche Signals from the Choroid Plexus Regulate Adult Neural Stem Cells. Cell Stem Cell 19: 643-652. https://doi.org/10.1016/j. stem.2016.06.013

TAVAZOIEM., VAN DER VEKEN L., SILVA-VARGAS V., LOUISSAINT M., COLONNA L., ZAIDI B., GARCIA-VERDUGO J. M., DOETSCH F. (2008). A Specialized Vascular Niche for Adult Neural Stem Cells. Cell Stem Cell 3: 279-288. https:// doi.org/10.1016/j.stem.2008.07.025

TOBA K., WINTON E. F., KOIKE T., SHIBATA A. (1995). Simultaneous three-color analysis of the surface phenotype and DNA-RNA quantitation using 7-aminoactinomycin D and pyronin Y. Journal of Immunological Methods 182: 193-207. https://doi.org/10.1016/0022-1759(95)00050-K

VAN DEN BERGE S. A., MIDDELDORP J., ZHANG C. E., CURTIS M. A., LEONARD B. W., MASTROENI D., VOORN P., VAN DE BERG W. D. J., HUITINGA I., HOL E. M. (2010). Longterm quiescent cells in the aged human subventricular neurogenic system specifically express GFAP- $\delta$. Aging Cell 9: 313-326. https://doi. org/10.1111/j.1474-9726.2010.00556.x

VAN KAMPEN J.M., ROBERTSON H.A. (2005). A possible role for dopamine D3 receptor stimulation in the induction of neurogenesis in the adult rat substantia nigra. Neuroscience 136:381-386. https://doi.org/10.1016/j.neuroscience.2005.07.054

VAN VELTHOVEN C. T.J., RANDO T. A. (2019). Stem Cell Quiescence: Dynamism, Restraint, and Cellular Idling. Cell Stem Cell 24:213-225. https://doi.org/10.1016/j. stem.2019.01.001

XIE M.Q., CHEN Z.C., ZHANG P., HUANG H.J., WANG T.T., DING Y.Q., QI S.S., ZHANG C., CHEN S.X., ZHOU P., SHAO C.C., LIAO M., SUN C.Y. (2017). Newborn dopaminergic neurons are associated with the migration and differentiation of SVZ-derived neural progenitors in a 6-hydroxydopamin-injected mouse model. Neuroscience 352: 64-78. https://doi.org/10.1016/j.neuroscience.2017.03.045

ZAMBONI M., LLORENS-BOBADILLA E., MAGNUSSON J. P., FRISÉN J. (2020). A Widespread Neurogenic Potential of Neocortical Astrocytes Is Induced by Injury. Cell Stem Cell 27: 605-617.e5. https://doi.org/10.1016/j.stem.2020.07.006

ZHOU H., SU J., HU X., ZHOU C., LI H., CHEN Z., XIAO Q., WANG B., WU W., SUN Y., ZHOU Y., TANG C., LIU F., WANG L., FENG C., LIU M., LI S., ZHANG Y., XU H., YAO H., SHI L., YANG H. (2020). Glia-to-Neuron Conversion by CRISPR-CasRx Alleviates Symptoms of Neurological Disease in Mice. Cell 181: 590-603.e16. https://doi.org/10.1016/j.cell.2020.03.024 